\title{
THE FIELD PRACTICE EVALUATION OF MAGELANG CHRISTIAN 2 VOCATIONAL SCHOOL
}

\author{
Adi Kristianto ${ }^{1}$, Ade Iriani $^{2}$, Wasitohadi ${ }^{3}$ \\ ${ }^{1}$ SMK Kristen 2 Magelang, Indonesia \\ ${ }^{2,3}$ Graduate Program Magister Of Education Management, FKIP, Universitas Kristen Satya \\ Wacana, Salatiga, Indonesia
}

E-mail: adikristianto@gmail.com¹ ade.iriani@uksw.edu², wasitohadiuksw@gmail.com³

\begin{abstract}
This study aims to evaluate the field work practice program (PKL) at the Christian Vocational High School 2 Magelang. This research is qualitative evaluative research, the technique of data collection is done by: observation, interview and documentation, this research uses the CIPP model (context, input, process, product). The results of the study are: (a) aspects of the context: this field work practice program is needed by students of the Christian 2 Vocational School of Magelang, the quality of students is very necessary. One way to improve the quality and achievement of students is through the PKL program; (b) input aspects: supporters of the PKL program are with implementation plans, schedules, implementation mechanisms, teachers, staff, funding, facilities and infrastructure both in schools and in the industrial world; (c) process aspects: Magelang 2 Christian Vocational School implements PKL programs in accordance with the regulations of the Directorate of Vocational High Schools. Where the process of implementing PKL program must be carried out well and involve students participating in PKL, schools and the industrial world as a place to carry out PKL; (d) product aspects: the field work practice program at Magelang Christian Vocational High School 2 Magelang proved to be useful for improving students skills and achievements.
\end{abstract}

Keywords: program evaluation, field work practices (PKL), CIPP.

\section{Introduction}

The development of human life demands to be better not to be separated from the quality of humans who are in it. Education is believed to always produce productive individuals and is believed to be able to make a nation progress, this is because the results of education are productive people. Education is an important factor in life, the purpose of education in the future must be able to provide solutions for development, namely the availability of qualified human beings so that they are able to accept rapid changes. (Sutarno, 2002: 1). The development of human resources in Indonesia is still felt to be not leading to the expected conditions. A person's behavior will affect his performance. (Koesmono, 2005). This can be seen from the mastery of competence and productivity of existing labor. Vocational School is one of the schools believed to be able to create innovative, creative and productive educational products. (Supriadi 2002: 17-18). This is because vocational education aims to produce productive human beings, namely human labor, not human burden for family, society, and nation. Therefore the level of vocational school is one of the best alternatives in order to improve the quality of Indonesian people as a whole. In the whole process of education in schools, learning activities are the main activities (Kunaryo, 2000: 21).

Quality education is characterized by graduates who have competence and are able to compete in the business world born from the implementation of good quality management. The ability of Vocational Schools to carry out quality management is currently a demand, so that graduates produced by this institution are able to overcome the problem of unemployment and employment which is still complained by the business world / industry. 
To create graduates who are reliable and in accordance with the demands of the business / industrial world of SMK, they must always be up to date on the progress and developments in the business world / industry. Vocational school as an education unit which is expected to be able to answer the demands of the business world / industrial world is obliged to hold a field work practice program (PKL). This is so that students can apply knowledge, specifically in their respective fields of expertise into the business world / industrial world. With the existence of this program, the industrial world as the place for PKL implementation benefited more, because the presence of PKL program participating in the industrial world could help the work that exists in the industrial world. This is due to the role of students as individuals who are applying their expertise in the business / industrial world. The field work program (PKL) also demands that the vocational school as the organizer of the program expand its network more with the business / industrial world. This is because there are many benefits obtained from the field work practice program (PKL), one of which is educating the independence of students in facing the conditions that exist in the business world I industrial world that are very different from those in school. With the existence of a field work practice program (PKL) in addition to students applying the knowledge gained in school, students can also train their skills into the business world / industrial world. Based on the results of observations, even though currently there are SMK graduates who can compete with higher education graduates, but this is still a small part of it and even then for graduates who do have high fighting ability and creativity.

One of the Vocational Schools that organizes field work (PKL) is Christianity 2 Magelang. To carry out this program, Magelang Christian Vocational School 2 carried out field work practices (PKL) for two months, in one school year. After the implementation of PKL program, symptoms are not good in students, namely students prefer to skip or do not come to school at the time they are supposed to use school. These students prefer not to attend school without a clear cause. The problem that arises from the field work practice program (PKL) at Christian 2 SMK Magelang is that it occurs in some students. The problematic students are due to the difference in hours of schooling with the hours of work during PKL. This study aims to evaluate PKL program' programs at Magelang 2 Christian Vocational School, based on aspects of context, input, process and product. The CIPP evaluation model was chosen because it was decision-oriented (Fitzpatrick, Sanders, \& Worthen, 2012), so that the results of this evaluative study were expected to provide recommendations to the management or Principal of the Christian 2 Vocational School of Magelang.

\section{Methods}

This study uses a qualitative descriptive approach. This research model is expected to be able to provide input and evaluation of the Magelang Vocational High School 2 Vocational School (PKL) practice program. In this study, the technique of data collection was done by: observation, interviews and documentation. The collected data involved the Principal of the Christian 2 Vocational School of Magelang, one of the representatives of the Teacher from the Student field and one of the representatives from the industrial world as an industry guide as long as the students did PKL program. The reason for the research was conducted at the Christian 2 Vocational School of Magelang because there had never been any research on the evaluation of PKL program' programs carried out at the Christian 2 Vocational School in Magelang. Interviews were conducted in the Principal's room and Teacher's room, and were at PT. Redja Abadi, a workshop and dealer for Mitsubishi vehicles. Flexibility in answering questions still exists, but still in control with prepared interview guidelines. Dialogue is recorded with the voice recorder application in the cellphone of the researcher. Observations immediately carried out. The study uses triangulation techniques to show the validation and validity of data.

\section{Result and Discussion Evaluation Context}

From the results of research that researchers have done at Magelang 2 Christian Vocational School regarding PKL programs, the school implemented the program based on the needs of: 
a. As a vocational school, Magelang 2 Christian Vocational School strives to stay ahead, and become the best school in Magelang City and district. The students' needs for achievement and skills are always sought by the school, so that the school always facilitates students through existing programs, one of which is this PKL program. The PKL program provides assistance in the form of strengthening student skills and improving student learning achievement.

b. In terms of context, the need for PKL program programs that have been programmed by the government through the Directorate of Vocational Education, at the Christian 2 Vocational School of Magelang to improve the quality of these students is aimed at increasing students' skills, confidence and of course other achievements. The PKL program has been implemented many years until now by the 2 Christian Vocational School of Magelang.

\section{Input Evaluation}

In the research at Magelang Christian 2 Vocational School, the resources owned to achieve the PKL program objectives included implementation plans, schedules, implementation mechanisms, teachers, staff, funding, facilities and infrastructure. Based on the results of research at Magelang Christian 2 Vocational School that in terms of the implementation plan the school prepares for this program at the beginning of the school year. The school also tried to choose the composition of students with each other and then adjusted to the place of PKL program. The budget is also prepared by the school every beginning of the school year. While in terms of the implementation mechanism, the school made special staff from the teacher to handle this program. The teachers are in charge of planning, finding new $\mathrm{PKL}$ program, establishing good relations with the industrial world and of course preparing all administration related to the implementation of $\mathrm{PKL}$ program.

In terms of human resources which include teachers and mechanics in the industry, the task is to handle this program, namely the teachers from the school they provide assistance for students who are carrying out $\mathrm{PKL}$ program, the task of these teachers is to assist students and monitor student activities during carry out PKL program. Then the mechanical duty in the industry is as a facilitator from the industrial side. The task of these mechanics is to provide assistance in the form of guidance, direction and transmit the sciences which are useful for PKL participants.

In terms of the source of funds for implementing the PKL program it is entirely from the school. In terms of facilities and infrastructure to support the PKL program is already fulfilling the requirements. This is inseparable from the practical facilities owned by the school, while the practice for students is used by the students of Magelang Christian 2 Vocational High School to conduct school learning, at least before implementing PKL program, students have already learned about vocational lessons using the practice tools starting from class $X$ until class $\mathrm{XI}$ in the odd semester, only then did the students carry out PKL program. The facilities owned by the industrial world are very in accordance with the fields and skills of students, in the implementation of PKL program students can use existing facilities owned by the industrial world. The similarity of the facilities used by students in the school and in the industrial world is very petrifying for students, in learning.

\section{Process Evaluation}

Preparations made by the 2 Christian Magelang Vocational School in the implementation of PKL program are to provide socialization to students and parents of students. The school also formed a special committee on the part of the teacher, one of which formed a companion, where the task of this companion was to assist and guide $\mathrm{PKL}$ participants. The school also contacted the industry, which is related to $\mathrm{PKL}$ programschedules, this is very important for the industry, specifically large industries such as PT. Bumen Redja Abadi as an authorized dealer and workshop for Mitsubishi vehicles. Process aspects in PKL 2 Christian Vocational School 2 Magelang activities include, preparations made by the school namely at the beginning of the PKL implementation or the first day of entering the PKL program, schools through the accompanying teacher formally giving PKL program to the industrial world, including submitting accident regulations work that is fully borne by the school. The accompanying teacher must ensure that 
all of his students have obtained a place for PKL program. At the beginning of the PKL program implementation, students usually feel awkward, this is natural because students do not know the new environment, but after a while students become accustomed to and feel comfortable when implementing PKL program. Students must comply with all applicable regulations in the industrial world, such as hours of entry, hours of rest and hours of return. There are several industries that implement shift systems, students must understand and comply with this. Obstacles in PKL program programs at Magelang 2 Christian Vocational School are PKL participants. That is in accordance with what was said by Mr. Mardi from PT. Redja Abadi, the official workshop and dealer for Mitsubishi vehicles, is that $P K L$ participating students have difficulty in serving consumers. This is due to the fact that PKL students are not used to communicating with others formally, and are not used to serving consumers. The industry considers this reasonable, and the industry is ready to train procedures in serving consumers. The second obstacle is after completing the PKL program. Students must go back to school, but found that there are a small number of these students having problems in attendance, often late for school and so on. The cause of this problem is due to differences in working hours in the industrial world with the hours of schooling, the role and assistance of parents of students needs to be done, so that students can get used to the hours of school entry.

Efektifitas program PKL di SMK Kristen 2 Magelang sudah sesuai dengan kebutuhan para siswa sebagai peserta PKL. Apabila mengacu pada pedoman PKL dari Direktorat Pembina SMK, SMK Kristen 2 Magelang telah mengupayakan program $P K L$ ini berjalan dengan baik dan lancar. Dengan adanya program PKL ini, siswa peserta PKL mendapatkan ketrampilan yang bermanfaat untuk kehidupan dimasa mendatang. Jadi bisa disimpulkan bahwa program PKL ini telah sesuai dengan kebutuhan siswa SMK Kristen 2 Magelang.

\section{Product Evaluation}

Results evaluation is an evaluation carried out to measure the success of achieving the stated goals. From the results of interviews that the researchers did, the achievement of the objectives of the program was proven by an increase in student academic achievement. In addition, student independence and character are becoming increasingly formed. Magelang 2 Christian Vocational School students have improved learning achievement and good character. One of these achievements was evidenced by students after carrying out PKL program, then they participated in the student skills competition held by the Central Java Provincial Education Office through the Light Vehicle Automotive Engineering (MGMP) Deliberation Council at Magelang City level. Magelang Christian 2 Vocational High School students won second place in the LKS championship. This is supported by the involvement of teachers, the world of industry and the means used by students to practice. So that the skills, good character of the students of Magelang Christian 2 Vocational High School after the PKL program have increased.

An example of the development of this good character is that after students finish implementing PKL program, they become more polite towards the teacher and school staff. Principals, Teachers and the industrial world hope that this PKL program will continue to be used in the future. This is due to the existence of the benefits of this PKL program very well. Schools as graduates and industrial printers as service users from graduates are very much helped by the existence of this PKL program.

\section{Conclusion}

1) Aspect of context: This PKL programprogram is needed by students of the Christian 2 Vocational School of Magelang. With the PKL program and students carrying out PKL program, students can apply vocational knowledge that has been obtained in school in learning theory and practice into the real world of work. Christian 2 SMK Magelang requires this $\mathrm{PKL}$ program as one of the qualified graduate printing programs.

2) Input aspects: PKL programs at Christian 2 SMK Magelang have been planned and designed according to the needs of the students. This PKL program is supported by human resources, 
funds and infrastructure that are very adequate and in accordance with the needs and competencies of students.

3) Aspects of the process: the implementation of this program is in accordance with the planned preparation. The process of activities is carried out by the school as a unit of education and collaborates with the industrial world to suit the competency needs of students. The role of mentoring is not only done by the school, but also by the industry. The quality of skills will increase as students have finished implementing PKL program. The obstacles to the PKL program are: 1) there are difficulties for students in serving consumers, indeed students have brought enough good skills from school, but there are still difficulties in how to serve consumers and this is natural because students are not used to meeting consumers . 2) After the PKL program are finished and students return to school, there are some students who experience a deterioration in the quality of attendance or are often late for school. This is due to the different hours of working with school hours.

4) Product aspects: The PKL program at Magelang 2 Christian Vocational School is in accordance with the initial plan. This program is also beneficial to the achievements of students as PKL program. Student skills are getting better, in addition to skills that increase student personality also increases. This better and better quality is proven by the success of getting second place in the Magelang City Student Skills Competition (LKS) in 2018.

This research is still lacking, so researchers suggest that researchers who will come to be able to complete all the shortcomings. For example, future researchers can use other evaluation models, for example Goal Oriented and Goal Free. The second example is to make a real product in the form of a PKL programguidebook for PKL program, teachers, principals and industry parties.

\section{References}

Arikunto, S dan Abdul Jabar, C.S. 2014 Evaluasi Program Pendidikan Pedoman Teoritis Praktis Bagi Mahasiswa dsn Praktisi Pendidikan. Jakarta: Bumi Aksara.

Badrujaman, Aip, M.Pd. 2011. Teori dan Aplikasi Evaluasi Program Bimbingan Konseling. Jakarta: PT. Indeks.

Direktorat Pembinaan Sekolah Menengah Kejuruan. 2017. Pedoman Praktek Kerja lapangan. Pembina Sekolah Menengah Kejuruan Direktoran Pendidikan dasar dan menenengah.

Eden, 2013. Out of the comfort zone: enhancing work-based learning about employability through student reflection on work placements. Department of Geography, Environment \& Earth Sciences, University of Hull, Cottingham Road, Hull HU6 7RX, UK. Diunduh Sabtu, 14 Juli 2018.

Eraut, Michael (2004) Informal Learning in the Workplace. University of Sussex, UK

https://www.emeraldinsight.com/doi/a bs/10.1108/14777281111159375.

Diunduh Jumat 27 Juli 2018.

Hadikusumo, Kunaryo. 1999. Pengantar Pendidikan. Semarang: IKIP Semarang Press.

Maleong, Lexy J. 2011. Metodologi Penelitian Kualitatif. Bandung: Remaja Rosdakarya.

Sugiyono, 2014. Metode Penelitian manajemen Pendekatan: Kuantitatif, Kualitatif, Kombinasi (Mixed Methods), Penelitian tindakan (Action Researc), Penelitian Evaluasi, Bandung: Alfabeta.

Sukardi, 2014. Evaluasi Program Pendidikan dan Kepelatihan, Jakarta : Bumi Aksara.

Syamhanim Ismail, 2014. A Comparison of the WBL Models and Implementation.

Faculty of Technical and Vocational Education, Sultan Idris University, 
Tanjung Malim, Perak. Diunduh Sabtu, 14 Juli 2018

Umi Khayatun Mardiyah dan Supriyadi, 2013. Evaluasi Praktik Kerja Industri Kompetensi Keahlian Pemasaran SMKN 1 Pengasih, Kulon Progo. Pendidikan Administrasi Perkantoran FE UNY ummikha@uny.ac.id Edy Supriyadi Fakultas Teknik Universitas Negeri Yogyakarta edy_via@yahoo.com. Diunduh Sabtu, 4 Agustus 2018.

Wena, Made. (1996). Pendidikan Sistem Ganda. Bandung: Tarsito.

Wirawan, 2012. Evaluasi Teori, Model, Standar, Aplikasi dan Profesi. Jakarta: PT Raja Grafindo Persada.

Wirawan, 2012. Model-model Evaluasi. https://tepenr06.wordpress.com/2012 /10/02/model-model-evaluasiprogram/ (Diakses pada Minggu 14 Oktober 2018, pukul 11.14)

Wirawan. 2017. Panduan Prakerin $2017 / 2018$.

https://smkdscreative.wordpress.com /prakerin/buku-pedoman-prakerintahun-pelajaran-2017-2018/ (Diakses pada Minggu, 14 Oktober 2018, pukul 21.05 WIB

Wirawan, 2005. Pengaruh Budaya Organisasi Terhadap Motivasi Dan Kepuasan Kerja Serta Kinerja Karyawan Pada Sub Sektor Industri Pengolahan Kayu Skala Menengah Di Jawa Timur ( Diakses pada Jumat, 15 Maret 2019, puku; 10.45 WIB) 